Electronic Supplementary Information for :

\title{
Oxidation and Acid Milieu-Disintegratable Nanovectors with Rapid Cell-Penetrating Helical Polymer Chains for Programmed Drug Release and Synergistic Chemo-Photothermal Therapy
}

\author{
Yu Chen, ${ }^{\ddagger}$ Zhi-Huang Zhang, ${ }^{\star}$ Xin Han, Jun Yin, ${ }^{*}$ and Zong-Quan $\mathrm{Wu}^{*}$ \\ Department of Polymer Science and Engineering, School of Chemistry and Chemical Engineering, Hefei University \\ of Technology and Anhui Key Laboratory of Advanced Functional Materials and Devices, Hefei, 230009, China.
}

\footnotetext{
*E-mail: yinjun@hfut.edu.cn (J.Y.), zqwu@hfut.edu.cn (Z.-Q.W.).
} 


\section{Instruments}

All the ${ }^{1} \mathrm{H},{ }^{13} \mathrm{C}$, and ${ }^{31} \mathrm{P}$ nuclear magnetic resonance (NMR) spectra were recorded using a Bruker 600 or $150 \mathrm{MHz}$ spectrometer operated in the Fourier Transform mode. Chemical shifts are reported in delta $(\delta)$ units and expressed in parts per million (ppm) downfield from tetramethylsilane using the residual proton solvent as an internal standard. Molecular weights and molecular weight distributions were determined using a size exclusion chromatograms (SEC) equipped with a Waters 1515 pump and a Waters 2414 differential refractive index detector (set at $40{ }^{\circ} \mathrm{C}$ ). A series of three linear Styragel columns (HR0.5, HR2, and HR4; $3.6 \times 300 \mathrm{~mm})$ was used at a temperature of $40{ }^{\circ} \mathrm{C}$. The eluent used was THF at a flow rate of $0.3 \mathrm{~mL} / \mathrm{min}$. FT-IR spectra were recorded on Perkin-Elmer Spectrum BX FT-IR system using KBr pellets at $25{ }^{\circ} \mathrm{C}$. Circular dichroism (CD) and UV-vis spectra were performed on JASCO J1500 and UNIC $4802 \mathrm{UV} / \mathrm{vis}$ double beam spectrophotometers, respectively. Quartz cells with 10.0 or $1.0 \mathrm{~mm}$ lengths were used in CD and UV-vis measurements. UV-vis spectra were performed on a UNIC 4802 UV/VIS double beam spectrophotometer in $1.0 \mathrm{~cm}$ length quartz cell. Fluorescence spectra were recorded using a RF-5301/PC (Shimadzu) spectrofluorometer. The temperature of the water-jacketed cell holder was controlled by a programmable circulation bath. The slit widths were set at $5.0 \mathrm{~nm}$ for both excitation and emission. Transmission electron microscopy (TEM) observations were conducted on a JEM-2100F electron microscope operating at an acceleration voltage of $200 \mathrm{kV}$. The samples for TEM observation were prepared by casting the corresponding solutions of polymers onto copper mesh grids and drying in air at room temperature. Samples for atomic force microscopy (AFM) measurements were prepared by drop casting solutions of polymers onto pre-cleaned silicon wafers and drying in air at room temperature. AFM images were obtained in tapping mode with a Digital Instruments Dimension 3100 Scanning Probe Microscope, performed at room temperature in air using standard silicon cantilevers with a nominal spring constant of $50 \mathrm{~N} / \mathrm{m}$ and resonance frequency of $\sim 300 \mathrm{kHz}$. Field-emission scanning electron microscope (FE-SEM) observations were conducted on a high-resolution JEOL JSM-6700 field-emission scanning electron microscopy. The samples for SEM observations were prepared by placing $10 \mu \mathrm{L}$ of microgel solutions on copper grids successively coated with thin films of Formvar and carbon. Dynamic light scattering (DLS) measurements were carried on a Nano-ZS90 Zetasizer of Malvern (UK) instrument, all data were averaged over three time measurements. 


\section{Materials}

All solvents were obtained from Sinopharm. Co. Ltd. and were purified by the standard procedures before use. THF was further dried over sodium benzophenone ketyl and distilled onto $\mathrm{LiAlH}_{4}$ under nitrogen just before use. Cyanine (IR780), 4-aminothiophenol, triethylamine, 4-aminobenzoic acid, 2-bromoethanol, 4-hydroxymethyl phenylboronic pinacol ester, trans-dichlorobis(triethylphosphine) palladium(II), propargyl bromide, L-lactic acid (L-LA), Nile red (NR), camptothecin (CPT), 1-(3-dimethylaminopropyl)-3-ethylcarbodiimide hydrochloride (EDCI), 1,5,7-triazabicyclo[4.4.0]dec-5-ene (TBD), $N$-hydroxybenzotriazole (HOBT), potassium carbonate, $N$-carbobenzyloxy-L-alanine, palladium-activated carbon (10\%), and pentane glycol monomethyl ether were purchased from Aladdin and Sigma-Aldrich and used as received without further purification. Water was deionized with a Milli-Q SP reagent water system (Millipore) to a specific resistivity of $18.0 \mathrm{M} \Omega \mathrm{cm}$. Lysotracker Red was purchased from Molecular Probes. Dulbecco's modified Eagle's medium (DMEM) were purchased from GIBCO and used as received. Pentafluorophenyl (PFP) ester-functionalized phenyl isocyanide monomer was synthesized in a similar way to our previously reported reference, ${ }^{1}$ the synthetic procedures and chemical structure characterization were shown in Figures $\mathrm{S} 1 . \mathrm{H}_{2} \mathrm{O}_{2}$-responsive phenyl isocyanide monomer $\left(\mathrm{M}_{2}\right)$, L-hydrophilic phenyl isocyanide monomer $\left(\mathrm{M}_{3}\right)$, and IR780/palladium(II) modified bifunctional catalyst $\left(\mathrm{ClPd}\left(\mathrm{PEt}_{3}\right)_{2}-\mathrm{IR} 780-\mathrm{OH}\right)$ were prepared according to previously reported reference with little modification. ${ }^{2,3}$ The corresponding chemical structure of the mediators in each step and final products were confirmed by ${ }^{1} \mathrm{H},{ }^{13} \mathrm{C},{ }^{31} \mathrm{P}$ NMR and FT-IR, as shown in Figures S2-S7.

\section{Sample Preparation}

Synthesis of $\mathrm{H}_{2} \mathrm{O}_{2}$-Responsive Phenyl Isocyanide Monomers $\left(\mathrm{M}_{2}\right.$; Figure $\left.\mathrm{S} 2 \mathrm{a}\right)$. In a typical run, into a $50 \mathrm{~mL}$ round bottom flask, pentafluorophenyl (PFP) ester-functionalized phenyl isocyanide monomer (0.50 g, $1.60 \mathrm{mmol})$, 4-hydroxymethyl phenylboronic pinacol ester (0.45 g, $1.90 \mathrm{mmol})$, triethylamine (0.65 g, $6.43 \mathrm{mmol})$, 4-dimethyl-aminopyridine $(80.0 \mathrm{mg}, 0.66 \mathrm{mmol})$, and anhydrous THF $(15 \mathrm{~mL})$ were charged. The resulting mixture was stirred at $30{ }^{\circ} \mathrm{C}$ for $12 \mathrm{~h}$. The solvent was removed by evaporation under reduced pressure. Then the residue was dissolved in $\mathrm{CH}_{2} \mathrm{Cl}_{2}(30 \mathrm{~mL})$ and washed successively with $\mathrm{H}_{2} \mathrm{O}(10 \mathrm{~mL} \times 2)$, saturated $\mathrm{NaHCO}_{3}$ solution $(10 \mathrm{~mL} \times 2)$, and brine 
$(10 \mathrm{~mL} \times 2)$. The solution was further dried over anhydrous $\mathrm{MgSO}_{4}$. After filtration, the solvent was removed by rotary evaporation under reduced pressure. The crude product was purified by column chromatography using petroleum ether/ethyl acetate $(\mathrm{v} / \mathrm{v}=1 / 1)$ as eluent to afford $\mathrm{M}_{2}$ as a light yellow oil (0.44 g, 75\% yield). ${ }^{1} \mathrm{H}$ NMR (600 MHz, $\mathrm{CDCl}_{3}, 25{ }^{\circ} \mathrm{C}$; Figure S2b): $\delta 8.09$ (d, 2H, ArH), 7.83 (d, 2H, $\mathrm{ArH}), 7.42-7.44$ (m, 4H, $\mathrm{ArH}), 5.37$ (s, 2H, $\left.-\mathrm{CH}_{2}-\mathrm{Ar}\right), 1.34$ (s, 12H, $\left.-\mathrm{C}-\mathrm{CH}_{3}\right) .{ }^{13} \mathrm{C}$ NMR (150 MHz, $\mathrm{CDCl}_{3}, 25^{\circ} \mathrm{C}$; Figure S2c): $\delta$ 168.84, 167.40, 141.02, 137.76, 133.61, 130.08, 129.14, 86.56, 69.84, 27.47. FT-IR (KBr, $\mathrm{cm}^{-1}, 25^{\circ} \mathrm{C}$; Figure S2d): 2128, 1759.

Synthesis of (S)-2,5,8,11,14-pentaoxahexadecan-16-yl-2(((benzyloxy)carbonyl) amino)propanoate (i). The reaction was performed through a condensation procedure. In a typical run, into a $250 \mathrm{~mL}$ round-bottom flask, $N$-carbobenzyloxy-L-alanine $(2.0 \mathrm{~g}, 8.96 \mathrm{mmol})$, pentane glycol monomethyl ether (2.49 g, $9.86 \mathrm{mmol})$, EDCI (2.06 g, $10.75 \mathrm{mmol})$, DMAP (0.55 g, $4.5 \mathrm{mmol})$, and anhydrous $\mathrm{CH}_{2} \mathrm{Cl}_{2}(100 \mathrm{~mL})$ were charged. The mixture was allowed to stir at room temperature for 12 hours. After removing the insoluble salts by suction filtration, the filtrate was concentrated by evaporation under reduced pressure and the crude product was further purified by silica gel column chromatography using petroleum ether/ethyl acetate $(\mathrm{v} / \mathrm{v}=1 / 1)$ as an eluent. After removing all the solvents, the final product (i) was obtained as a light yellow liquid (3.0 g, yielding: $75 \%$ ). ${ }^{1} \mathrm{H}$ NMR $\left(600 \mathrm{MHz}, \mathrm{CDCl}_{3}, 25^{\circ} \mathrm{C}\right.$; Figure S3b1): $\delta$ 7.26-7.31 (m, 5H, ArH), 5.07 (s, 2H, Ar- $\mathrm{CH}_{2^{-}}$), 4.37 (q, $\left.1 \mathrm{H},-\mathrm{CH}-\mathrm{CH}_{3}\right), 4.26\left(\mathrm{t}, 2 \mathrm{H},-\mathrm{CH}_{2}-\mathrm{CH}_{2}-\right), 3.49-3.62\left(\mathrm{~m}, 18 \mathrm{H},-\mathrm{CH}_{2}-\right), 3.34\left(\mathrm{~s}, 3 \mathrm{H},-\mathrm{O}-\mathrm{CH}_{3}\right), 1.39$ (d, $\left.3 \mathrm{H},-\mathrm{CH}-\mathrm{CH}_{3}\right)$.

Synthesis of (S)-2,5,8,11,14-pentaoxahexadecan-16-yl-2-aminopropanoate (ii). In a typical run, into a $250 \mathrm{~mL}$ round-bottom flask, compound $\mathbf{i}(3.0 \mathrm{~g}, 6.56 \mathrm{mmol})$ and $10 \%$ palladium-activated carbon $(0.3 \mathrm{~g})$ were charged. After completely degassed for $30 \mathrm{~min}$ by $\mathrm{H}_{2}$, dry THF $(100 \mathrm{~mL})$ were injected to the mixture via a syringe. The mixture was allowed to stir at room temperature for $12 \mathrm{~h}$ under an atmosphere of $\mathrm{H}_{2}$. After filtration, the solvent was removed to give the product (ii) as a light yellow liquid (1.8 g, yielding: $85 \%$ ). ${ }^{1} \mathrm{H} \mathrm{NMR}\left(600 \mathrm{MHz}, \mathrm{CDCl}_{3}, 25{ }^{\circ} \mathrm{C}\right.$; Figure S3b2): $\delta 4.21$ (t, $2 \mathrm{H}$, $-\mathrm{CH}_{2}-\mathrm{CH}_{2}$ ), 3.65 (q, $\left.1 \mathrm{H},-\mathrm{CH}-\mathrm{CH}_{3}\right), 3.48-3.60\left(\mathrm{~m}, 18 \mathrm{H},-\mathrm{CH}_{2}-\right), 3.32$ (s, 3H, $\left.-\mathrm{O}-\mathrm{CH}_{3}\right), 1.28(\mathrm{~d}, 3 \mathrm{H}$, $\left.-\mathrm{CH}-\mathrm{CH}_{3}\right)$.

Synthesis of L-Hydrophilic Phenyl Isocyanide Monomer (M3; Figure S3a). In a typical run, into a 50 $\mathrm{mL}$ round bottom flask, PFP ester-functionalized phenyl isocyanide (1.45 g, $4.60 \mathrm{mmol})$, compound 
ii (1.8 g, $5.57 \mathrm{mmol})$, TEA (1.87 g, $18.53 \mathrm{mmol})$, DMAP (0.28 g, $2.32 \mathrm{mmol})$, and anhydrous THF $(30 \mathrm{~mL})$ were charged. The resulting mixture was stirred at ambient temperature for $12 \mathrm{~h}$. The solvent was removed by evaporation under reduced pressure. Then, the residue was redissolved in $\mathrm{CH}_{2} \mathrm{Cl}_{2}(30 \mathrm{~mL})$ and washed successively with $\mathrm{H}_{2} \mathrm{O}(10 \mathrm{~mL} \times 2)$ and brine $(10 \mathrm{~mL} \times 2)$, and dried over anhydrous $\mathrm{Na}_{2} \mathrm{SO}_{4}$. After filtration, the solvent was removed by evaporation under reduced pressure. The crude product was further purified by column chromatography using petroleum ether/ethyl acetate $(\mathrm{v} / \mathrm{v}=1 / 3)$ as eluent to afford $\mathrm{M}_{3}$ as a light yellow oil $(1.8 \mathrm{~g}$, yielding: $86 \%) .{ }^{1} \mathrm{H}$ NMR (600 MHz, $\mathrm{CDCl}_{3}, 25^{\circ} \mathrm{C}$; Figure S3b3): $\delta 7.89(\mathrm{~d}, 2 \mathrm{H}, \mathrm{ArH}), 7.45(\mathrm{~d}, 2 \mathrm{H}, \mathrm{ArH}), 4.83(\mathrm{q}, 1 \mathrm{H}$, $\left.-\mathrm{CH}-\mathrm{CH}_{3}\right), 4.33\left(\mathrm{t}, 2 \mathrm{H},-\mathrm{CH}_{2}-\mathrm{CH}_{2}-\right), 3.72\left(\mathrm{t}, 2 \mathrm{H},-\mathrm{CH}_{2}-\mathrm{CH}_{2}-\right), 3.52-3.63\left(\mathrm{~m}, 16 \mathrm{H},-\mathrm{CH}_{2}-\right), 3.35(\mathrm{~s}, 3 \mathrm{H}$, $\left.-\mathrm{O}-\mathrm{CH}_{3}\right), 1.43\left(\mathrm{~d}, 3 \mathrm{H},-\mathrm{CH}-\mathrm{CH}_{3}\right) .{ }^{13} \mathrm{C} \mathrm{NMR}\left(150 \mathrm{MHz}, \mathrm{CDCl}_{3}, 25^{\circ} \mathrm{C}\right.$; Figure $\left.\mathrm{S} 4\right): \delta 167.15,164.55$, $130.72,129.68,125.76,71.64,70.31,70.22,70.10,68.72,64.30,58.52,28.57$.

Synthesis of aniline-modified IR780 (iii; Figure S5a). Typically, into a $50 \mathrm{~mL}$ round-bottomed flask, IR780 (1.0 g, $1.50 \mathrm{mmol})$, 4-aminothiophenol (0.56 g, $4.50 \mathrm{mmol})$, anhydrous DMF (15 mL), and triethylamine $(10 \mu \mathrm{L})$ were charged and the mixture was allowed to stir overnight at room temperature. Then, the solvent was concentrated and the crude product was purified by column chromatography using $\mathrm{CH}_{2} \mathrm{Cl}_{2} / \mathrm{MeOH}(\mathrm{v} / \mathrm{v}=10 / 1)$ as eluent to afford compound (iii) as dark green crystals $\left(0.73 \mathrm{~g}, 61.7 \%\right.$ yield). ${ }^{1} \mathrm{H}$ NMR (600 MHz, DMSO- $d_{6}, 25{ }^{\circ} \mathrm{C}$; Figure S5b): $\delta 8.72(\mathrm{~d}, 2 \mathrm{H}$, $-\mathrm{CH}=\mathrm{CH}-), 6.51-7.54(\mathrm{~m}, 12 \mathrm{H}, \mathrm{ArH}), 6.29(\mathrm{~d}, 2 \mathrm{H},-\mathrm{CH}=\mathrm{CH}-), 5.14\left(\mathrm{~s}, 2 \mathrm{H},-\mathrm{NH}_{2}\right), 4.15(\mathrm{t}, 4 \mathrm{H}$, $\left.-\mathrm{CH}_{2}-\mathrm{CH}_{2}-\right), 2.70$ (t, 4H, $\left.-\mathrm{CH}_{2}-\mathrm{CH}_{2}-\right), 1.87$ (t, $\left.2 \mathrm{H},-\mathrm{CH}_{2}-\right), 1.74$ (q, 4H, $\left.-\mathrm{CH}_{2}-\mathrm{CH}_{3}\right), 1.55(\mathrm{~s}, 12 \mathrm{H}$, $\left.-\mathrm{C}-\mathrm{CH}_{3}\right), 0.95\left(\mathrm{t}, 6 \mathrm{H},-\mathrm{CH}_{2}-\mathrm{CH}_{3}\right)$.

Synthesis of 4-(prop-2-yn-1-ylamino)benzoic acid (v). Typically, into a $100 \mathrm{~mL}$ round-bottomed flask, propargyl bromide (3.3 g, $28 \mathrm{mmol}), 4$-aminobenzoic acid (3.8 g, $28 \mathrm{mmol}), \mathrm{K}_{2} \mathrm{CO}_{3}(3.9 \mathrm{~g}, 28 \mathrm{mmol})$, and anhydrous $\mathrm{CH}_{3} \mathrm{CN}(50 \mathrm{~mL})$ were charged and the mixture was allowed to stir at room temperature under $\mathrm{N}_{2}$ atmosphere for 3 hours. The mixture was then washed with saturated $\mathrm{NaHCO}_{3}$ as well as brine. The organic phase was concentrated and further purified by silica gel column chromatography using ethyl acetate/petroleum ether $(\mathrm{v} / \mathrm{v}=1 / 6)$ as eluent. After dried over anhydrous $\mathrm{MgSO}_{4}$ and removing all the solvents, compound $\mathbf{v}(5.0 \mathrm{~g}$; yield: $70.4 \%)$ was obtained as a yellow solid. ${ }^{1} \mathrm{H}$ NMR (600 MHz, $\mathrm{CDCl}_{3}, 25{ }^{\circ} \mathrm{C}$; Figure S6b): $\delta 7.86(\mathrm{~d}, 2 \mathrm{H}, \mathrm{ArH}), 6.63(\mathrm{~d}, 2 \mathrm{H}, \mathrm{ArH}), 4.85$ $\left(\mathrm{d}, 2 \mathrm{H}, \equiv \mathrm{C}-\mathrm{CH}_{2}-\right), 2.48$ (t, $\left.1 \mathrm{H},-H \mathrm{C} \equiv \mathrm{C}-\right)$.

Synthesis of 4-((2-hydroxyethyl)(prop-2-yn-1-yl)amino)benzoic acid (vi). Typically, into a $50 \mathrm{~mL}$ 
round-bottom flask, 2-bromoethanol $(4.9 \mathrm{~g}, 39 \mathrm{mmol})$, potassium carbonate $(1.8 \mathrm{~g}, 13 \mathrm{mmol})$, and anhydrous DMF $(30 \mathrm{~mL})$ were charged. The mixture was allowed to stir for 10 minutes. At the same time, into another $100 \mathrm{~mL}$ round-bottom flask, compound $\mathbf{v}(2.3 \mathrm{~g}, 13 \mathrm{mmol})$, potassium carbonate $(0.9 \mathrm{~g}, 6.5 \mathrm{mmol})$, and anhydrous DMF $(10 \mathrm{~mL})$ were also charged and allowed to stir for 10 minutes. Then, the 2-bromoethanol solution was added to compound $\mathbf{v}$. The mixture was heated to $60{ }^{\circ} \mathrm{C}$ under $\mathrm{N}_{2}$ atmosphere and allowed to stir for 48 hours. The solvent was concentrated in vacuo after being cooled, water $(30 \mathrm{~mL})$ was subsequently added and extracted with $\mathrm{CHCl}_{3}(30 \mathrm{~mL} \times 3)$. The organic phase was collected and concentrated under reduced pressure. The crude product was further purified by silica gel column chromatography using petroleum ether/ethyl acetate $(\mathrm{v} / \mathrm{v}=5 / 1)$ as eluent. After removing all the solvents, compound vi (2.56 g; yield: 65\%) was obtained as a yellow solid. ${ }^{1} \mathrm{H}$ NMR (600 MHz, $\mathrm{CDCl}_{3}, 25{ }^{\circ} \mathrm{C}$; Figure S6b): $\delta 7.87$ (d, 2H, ArH), $6.56(\mathrm{~d}, 2 \mathrm{H}, \mathrm{ArH}), 4.85$ $\left(\mathrm{d}, 2 \mathrm{H}, \equiv \mathrm{C}-\mathrm{CH}_{2}-\right), 3.86\left(\mathrm{t}, 2 \mathrm{H},-\mathrm{CH}_{2}-\mathrm{CH}_{2}-\right), 3.35$ (t, 2H, $\left.-\mathrm{CH}_{2}-\mathrm{CH}_{2}-\right), 2.48(\mathrm{t}, 1 \mathrm{H},-\mathrm{C} \equiv \mathrm{CH})$. Synthesis of Hydroxyl and Palladium(II) Modified 4-Aminobenzoic Acid (iv; Figure S6a). Typically, in a $100 \mathrm{~mL}$ round-bottomed flask, compound vi $(39.0 \mathrm{mg}, 0.18 \mathrm{mmol})$ was treated with trans-dichlorobis (triethylphosphine)palladium (125 $\mathrm{mg}, 0.3 \mathrm{mmol}$ ) in the presence of copper(I) chloride $(5.0 \mathrm{mg}, 0.05 \mathrm{mmol})$ as catalyst in $20 \mathrm{~mL}$ of anhydrous diethylamine and $20 \mathrm{~mL}$ of anhydrous dichloromethane. The mixture was stirred at room temperature for $3 \mathrm{~h}$. After the solvent was removed under reduced pressure, the residue was further purified by silica gel column chromatography with petroleum ether/ethyl acetate $(\mathrm{v} / \mathrm{v}=4 / 1)$ as eluent. After removing all the solvents, compound iv (70 mg; yield: 62\%) was obtained as a pale-yellow solid. ${ }^{1} \mathrm{H}$ NMR (600 MHz, $\mathrm{CDCl}_{3}, 25{ }^{\circ} \mathrm{C}$; Figure S6b): $\delta 7.86(\mathrm{~d}, 2 \mathrm{H}, \mathrm{ArH}), 6.60(\mathrm{~d}, 2 \mathrm{H}, \mathrm{ArH}), 4.89\left(\mathrm{~d}, 2 \mathrm{H},-\mathrm{CH}_{2}-\mathrm{C} \equiv\right), 3.87(\mathrm{t}$, $\left.2 \mathrm{H},-\mathrm{CH}_{2}-\mathrm{CH}_{2}-\right), 3.37$ (t, $\left.2 \mathrm{H},-\mathrm{CH}_{2}-\mathrm{CH}_{2^{-}}\right), 1.88-1.96\left(\mathrm{~m}, 12 \mathrm{H},-\mathrm{P}\left(\mathrm{CH}_{2}-\mathrm{CH}_{3}\right)_{3}\right), 1.10-1.19$ (m, $18 \mathrm{H}$, $\left.-\mathrm{P}\left(\mathrm{CH}_{2}-\mathrm{CH}_{3}\right)_{3}\right)$.

Synthesis of Near Infrared Dye (IR780) and Palladium(II) Modified Bifunctional Catalyst

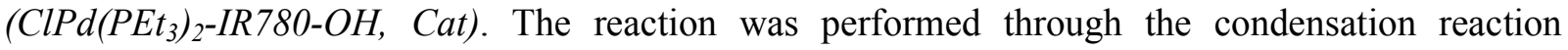
between aniline-modified IR780 (iii) and hydroxyl/palladium(II)-modified 4-aminobenzoic acid (iv), the synthesis procedure was shown in Figure S7a. In a typical run, into a $100 \mathrm{~mL}$ round-bottomed flask, compound iii (0.6 g, $0.79 \mathrm{mmol})$, compound iv (0.56 g, $0.95 \mathrm{mmol})$, EDCI (0.22 g, $1.14 \mathrm{mmol})$, $\operatorname{HOBT}(0.15 \mathrm{~g}, 1.14 \mathrm{mmol})$, and anhydrous $\mathrm{CH}_{2} \mathrm{Cl}_{2}(10 \mathrm{~mL})$ were charged. The mixture was allowed to stir overnight. Then, the solution was filtered to remove salt, and water was added to the filtrate 
and the aqueous layer was extracted with $\mathrm{CH}_{2} \mathrm{Cl}_{2}(15 \mathrm{~mL} \times 3)$. The combined organic layer was washed with water and dried over anhydrous $\mathrm{Na}_{2} \mathrm{SO}_{4}$, filtered, and concentrated in vacuo. The crude product was further purified by silica gel column chromatography using $\mathrm{CH}_{2} \mathrm{Cl}_{2} / \mathrm{MeOH}(\mathrm{v} / \mathrm{v}=30 / 1)$ as the eluent to obtain $\mathrm{ClPd}\left(\mathrm{PEt}_{3}\right)_{2}-\mathrm{IR} 780-\mathrm{OH}$ as a breen solid $(0.69 \mathrm{~g}, 65.0 \%$ yield $)$. The chemical structure was confirmed by ${ }^{1} \mathrm{H}$ NMR, ${ }^{13} \mathrm{C}$ NMR, and FT-IR spectra, shown in Figures S7b-S7e. ${ }^{1} \mathrm{H}$ NMR (600 MHz, $\mathrm{CDCl}_{3}, 25{ }^{\circ} \mathrm{C}$; Figure S7b): $\delta 8.64$ (d, 2H, $\left.-\mathrm{CH}=\mathrm{CH}-\right), 7.10-7.41(\mathrm{~m}, 14 \mathrm{H}, \operatorname{Ar} H)$, $6.98(\mathrm{~d}, 2 \mathrm{H}, \mathrm{Ar} H), 6.24$ (d, 2H, $-\mathrm{CH}=\mathrm{CH}-), 4.41\left(\mathrm{~s}, 2 \mathrm{H},-\mathrm{CH}_{2}-\mathrm{C} \equiv\right), 4.18$ (t, 4H, $\left.-\mathrm{CH}_{2}-\mathrm{CH}_{2}-\right), 3.83$ (t, $\left.2 \mathrm{H},-\mathrm{CH}_{2}-\mathrm{CH}_{2-}\right), 2.64\left(\mathrm{t}, 2 \mathrm{H},-\mathrm{CH}_{2}-\mathrm{CH}_{2}-\right), 2.54$ (t, 4H, $-\mathrm{CH}_{2}-\mathrm{CH}_{2}$ ), 1.92 (q, 4H, $\left.-\mathrm{CH}_{2}-\mathrm{CH}_{3}\right)$, 1.80-1.83 (m, 12H, - $\left.\mathrm{P}\left(\mathrm{CH}_{2}-\mathrm{CH}_{3}\right)_{3}\right), 1.01\left(\mathrm{t}, 6 \mathrm{H},-\mathrm{CH}_{2}-\mathrm{CH}_{3}\right), 1.66\left(\mathrm{~s}, 12 \mathrm{H},-\mathrm{C}-\mathrm{CH}_{3}\right), 1.09$ (t, 2H, $\left.-\mathrm{CH}_{2}-\mathrm{CH}_{2-}\right)$ 1.00-1.08 (m, 18H, $\left.-\mathrm{P}\left(\mathrm{CH}_{2}-\mathrm{CH}_{3}\right)_{3}\right) .{ }^{13} \mathrm{C} \mathrm{NMR}\left(150 \mathrm{MHz}, \mathrm{CDCl}_{3}, 25^{\circ} \mathrm{C}\right.$; Figure $\left.\mathrm{S} 7 \mathrm{c}\right)$ : $\delta 175.58,155.20,149.17,144.87,143.35,139.77,135.95,131.86,129.79,128.27,125.75,125.09$, $113.42,103.72,55.08,52.04,48.45,35.12,30.64,28.91,27.62,27.15,23.50,14.36 .{ }^{31} \mathrm{P}$ NMR $(121.5$ $\mathrm{MHz}, \mathrm{CDCl}_{3}, 25^{\circ} \mathrm{C}$; Figure S7d): $\delta$ 17.91. FT-IR $\left(\mathrm{KBr}, \mathrm{cm}^{-1}, 25^{\circ} \mathrm{C}\right.$; Figure S7e): $3369.45,2961.97$, 2143.34, 1687.60.

One-Pot Sequential Copolymerization of L-LA $\left(M_{1}\right), \mathrm{H}_{2} \mathrm{O}_{2}$-Responsive Phenyl Isocyanide Monomer $\left(\mathrm{M}_{2}\right)$, and L-Hydrophilic Phenyl Isocyanide Monomer $\left(\mathrm{M}_{3}\right)$ with ClPd(PEt $\left.{ }_{3}\right)_{2}-I R 780-\mathrm{OH}$ as a Single Catalyst. The reaction was performed in a similar way to the previously reported reference, ${ }^{3}$ the synthesis procedure was shown in Scheme 2. In a typical run, a $25 \mathrm{~mL}$ oven-dried flask was charged with $\mathrm{ClPd}\left(\mathrm{PEt}_{3}\right)_{2}-\mathrm{IR} 780-\mathrm{OH}$ catalyst $(13.34 \mathrm{mg}, 0.01 \mathrm{mmol}), \mathrm{M}_{1}\left(43.24 \mathrm{mg}, 0.3 \mathrm{mmol} ;[\mathrm{M}]_{0} /[\mathrm{I}]_{0}=\right.$ 30), $\mathrm{M}_{2}\left(108.97 \mathrm{mg}, 0.3 \mathrm{mmol} ;[\mathrm{M}]_{0} /[\mathrm{I}]_{0}=30\right)$, and anhydrous 1,2-dichloroethane $(5.0 \mathrm{~mL})$. To this stirring mixture was added a solution of TBD $(0.01 \mathrm{mmol})$ in 1,2-dichloroethane via a syringe at ambient temperature. The mixture was allowed to stir at $80^{\circ} \mathrm{C}$, and the copolymerization progress was monitored by size exclusion chromatograms (SEC) until the molecular weight of PLLA(-IR780)-HBPPI ceased to increase $\left(M_{\mathrm{n}}=12.8 \mathrm{kDa}, M_{\mathrm{w}} / M_{\mathrm{n}}=1.18\right)$. Subsequently, under nitrogen atmosphere, $\mathrm{M}_{3}\left(181.4 \mathrm{mg}, 0.4 \mathrm{mmol} ;[\mathrm{M}]_{0} /[\mathrm{I}]_{0}=40\right)$ was added via a syringe, and the copolymerization was stirred at $80{ }^{\circ} \mathrm{C}$ for another $24 \mathrm{~h}$. Then, the copolymerization solution was precipitated into a large amount of cold diethyl ether, collected by centrifugation, and dried in vacuum at ambient temperature overnight to afford the triblock copolymer PLLA(-IR780)-HBPPI-HPPPI. The molecular weight and molecular weight distribution of 
PLLA(-IR780)-HBPPI-HPPPI were determined by SEC using THF as the eluent, revealing an $M_{\mathrm{n}}$ of $30.1 \mathrm{kDa}$ and an $M_{\mathrm{w}} / M_{\mathrm{n}}$ of 1.17 . The chemical structure was confirmed by ${ }^{1} \mathrm{H}$ NMR and the actual DP of PLLA, HBPPI, and HPPPI were determined to be $\sim 20, \sim 25$, and $\sim 35$, respectively, based on ${ }^{1} \mathrm{H}$ NMR and SEC results.

Self-Assembly of PLLA(-IR780)-HBPPI-HPPPI Triblock Copolymers. Typically, $4.0 \mathrm{mg}$ of triblock copolymer was dissolved in $0.5 \mathrm{~mL}$ of $\mathrm{THF}$, the solution was stirred and maintained for $30 \mathrm{~min}$ at room temperature. Under vigorous stirring, $1.5 \mathrm{~mL}$ of DI water was added via a syringe pump at a flow rate of $0.05 \mathrm{~mL} / \mathrm{min}$. After the addition was completed, the dispersion was left stirring for another $12 \mathrm{~h}$. THF was then removed by dialysis (MWCO $3.5 \mathrm{kDa}$ ) against pure water for $24 \mathrm{~h}$. Fresh water was replaced approximately every $6 \mathrm{~h}$. The obtained dispersion with a characteristic of colloidal aggregates did not exhibit any macroscopic phase separation upon standing at room temperature for more than 10 days, suggesting the formation of stable aggregates. Following the same procedure, self-assembly of HBPPI-HPPPI and PLLA-HPPPI diblock copolymers were also performed.

Preparation of Anti-Cancer Drug (CPT) Loaded Polymeric Micelles. Hydrophobic CPT molecules were loaded into the hydrophobic region during the co-solvent self-assembly process. Typically, the THF solutions of PLLA(-IR780)-HBPPI-HPPPI triblock copolymers (20 g/L) and CPT (4.0 g/L) were prepared in advance, respectively, and mixed together. A similar self-assembly procedure was performed upon a slow DI water addition as mentioned above. The final mixture was vacuumed to remove the organic solvent. Free CPT were removed by passing through a $0.22 \mu \mathrm{m}$ Millipore filter. The final micellar dispersion was diluted with phosphate buffer solution (PBS; $\mathrm{pH}$ 7.4). To determine the contents of CPT, an aliquot of CPT@PLLA(-IR780)-HBPPI-HPPPI micellar solution was dissolved in DMSO. The CPT encapsulation efficiency and loading content were calculated to be $\sim 73.22 \mathrm{wt} / \mathrm{wt} \%$ and $\sim 6.4 \mathrm{wt} / \mathrm{wt} \%$ based on the absorbance of CPT at $355 \mathrm{~nm}$ against standard calibration curves. Encapsulation efficiency $(\%)=($ weight of molecules in the micelles / weight of the feeding molecules $) \times 100 \%$; Loading content $(\%)=($ weight of molecules $) /($ weight of molecules + weight of polymer $) \times 100 \%$. Following the same procedure, NR@PLLA(-IR780)-HBPPI-HPPPI micelles were also prepared.

Preparation of NR-Loaded Polymeric Micelles. Hydrophobic NR was loaded into the HBPPI-HPPPI and PLLA-HPPPI diblock copolymers during the co-solvent self-assembly process. Typically, take 
HBPPI-HPPPI for example, the initial concentrations of HBPPI-HPPPI and NR in THF were 3.0 and $0.01 \mathrm{~g} / \mathrm{L}$, respectively. A similar self-assembly procedure was then performed upon a slow DI water addition as detailed above. After removal of THF via dialysis (MWCO $3.5 \mathrm{kDa}$ ) against pure water, the NR@HBPPI-HPPPI micellar dispersion was stored for further use. Following the same procedure, NR@PLLA-HPPPI micellar dispersion was also prepared. The loading content for NR were calculated based on the emission spectra of NR $\left(\lambda_{\text {ex }}: 550 \mathrm{~nm}\right)$ against a standard calibration curve.

In Vitro Fluorescence Imaging. Fluorescence images of NR@HBPPI-HPPPI micelles internalized HeLa cells were acquired using an inverted Leica SP2 confocal microscope at $37^{\circ} \mathrm{C}$. The samples were excited at $550 \mathrm{~nm}$ for NR, and the fluorescence was collected between 580-700 $\mathrm{nm}$ for the red channel. All confocal laser scanning microscopy (CLSM) images were taken under the same conditions for parallel comparison. For CPT@PLLA(-IR780)-HBPPI-HPPPI samples, the fluorescence was excited at $405 \mathrm{~nm}$, and the fluorescence was collected between 410-500 $\mathrm{nm}$ for the red channel. The late endosomes and lysosomes were stained with Lysotracker Red upon incubation with cells for 30 min before imaging at $200 \mathrm{nM}$ and observed using a $594 \mathrm{~nm}$ laser, and the emission wavelength was read from 605 to $720 \mathrm{~nm}$ and expressed as red.

In Vitro Dye Release Profile of NR from the Micelles. The NR release from various micelles was measured by the dialysis method. Briefly, NR@PLLA(-IR780)-HBPPI-HPPPI micellar dispersion $(0.5 \mathrm{~g} / \mathrm{L}$ in PBS; $5 \mathrm{~mL})$ was placed in a dialysis tube (MWCO is $3500 \mathrm{Da})$ and then immersed into $250 \mathrm{~mL}$ of PBS with Tween 20 (1\% total volume) under gentle stirring at $37^{\circ} \mathrm{C}$. The system treated with or without $\mathrm{H}_{2} \mathrm{O}_{2}$ was according to the need. At different time intervals, the emission intensity of micellar dispersion was recorded and quantified against a standard calibration curve.

Cell Culture and in Vitro Cytotoxicity Assessment of CPT@PLLA(-IR780)-HBPPI-HPPPI micelles. HeLa cells $(5 \times 103$ cells/well) in Dulbecco's modified Eagle's medium (DMEM) complete medium were plated into a 96-well plate and incubated overnight. HeLa cells were then exposed to CPT@ PLLA(-IR780)-HBPPI-HPPPI micelles $(0,0.1,0.2$, and $0.4 \mathrm{~g} / \mathrm{L})$ at $37{ }^{\circ} \mathrm{C}$ for up to $6 \mathrm{~h}$ in DMEM complete medium. Then, cells were rinsed with PBS buffer and DMEM complete medium. Cytotoxicity was assessed by adding 3-(4,5-dimethyl-2-thiazolyl)-2,5-diphenyl tetrazolium bromide (MTT) for another 4h. Cells incubated with PBS only were served as positive control. For comparison, the cytotoxicity of empty PLLA(-IR780)-HBPPI-HPPPI micelles were also assessed 
following the same procedures.

PhotothermalEffect of CPT@PLLA(-IR780)-HBPPI-HPPPI Complex. For photothermal efficiency measurements, 1.0 mL of CPT@PLLA(-IR780)-HBPPI-HPPPI micellar dispersion (2.0 g/L; pH 7.4) was charged into a cuvette, the dispersion temperature after being subjected to NIR light (808 nm, $1.0 \mathrm{~W} \mathrm{~cm}^{-2}$ ) irradiation for varying times was directly measured by a digital thermometer probe. For comparison, pure PBS buffer was also tested. The temperature of micellar dispersion and PBS buffer after laser irradiation were also recorded with an infrared thermal image instrument.

\section{References}

(1) Su, M.; Liu, N.; Wang, Q.; Wang, H. Q.; Yin, J.; Wu, Z. Q. Facile synthesis of poly(phenyleneethynylene)-block-polyisocyanide copolymers via two mechanistically distinct, sequential living polymerizations using a single catalyst. Macromolecules 2016, 49, 110-119.

(2) Song, C. C.; Ji, R.; Du, F. S.; Liang, D. H.; Li, Z.C. Oxidation-accelerated hydrolysis of the ortho ester-containing acid-labile polymers. ACS Macro Lett. 2013, 2, 273-277.

(3) Shi, S. Y.; Liu, Y. J.; Chen, Y.; Zhang, Z. H.; Ding, Y. S.; Wu, Z. Q.; Yin, J.; Nie, L. M. Versatile pH-response micelles with high cell-penetrating helical diblock copolymers for photoacoustic imaging guided synergistic chemo-photothermal therapy. Theranostics, 2016, 6, 2170-2182. 
a)

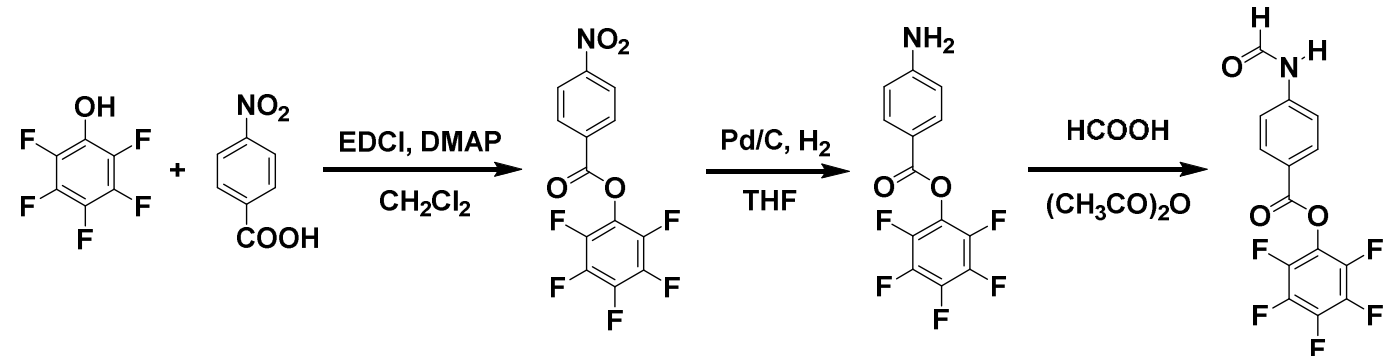

b)
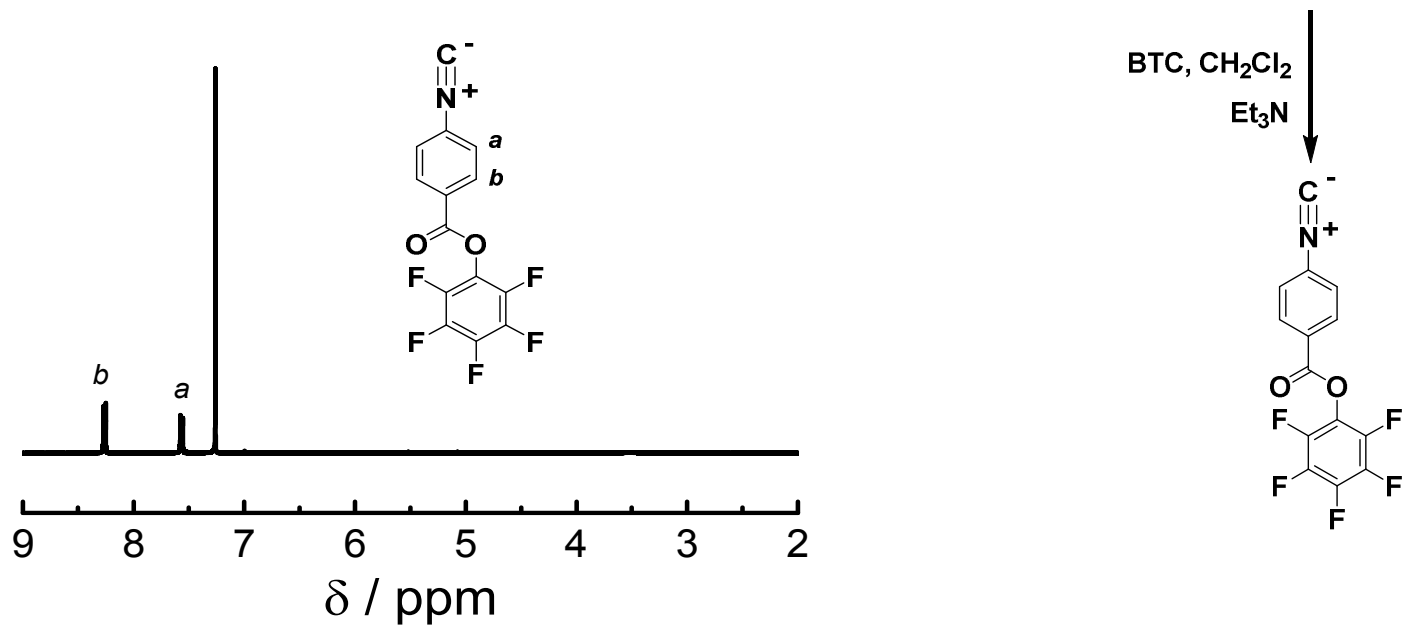

Figure S1. (a) Synthetic route employed for the preparation of pentafluorophenyl (PFP) ester -functionalized phenyl isocyanide monomer. (b) ${ }^{1} \mathrm{H}$ NMR spectrum obtained for the PFP ester-functionalized phenyl isocyanide monomer. 
a)
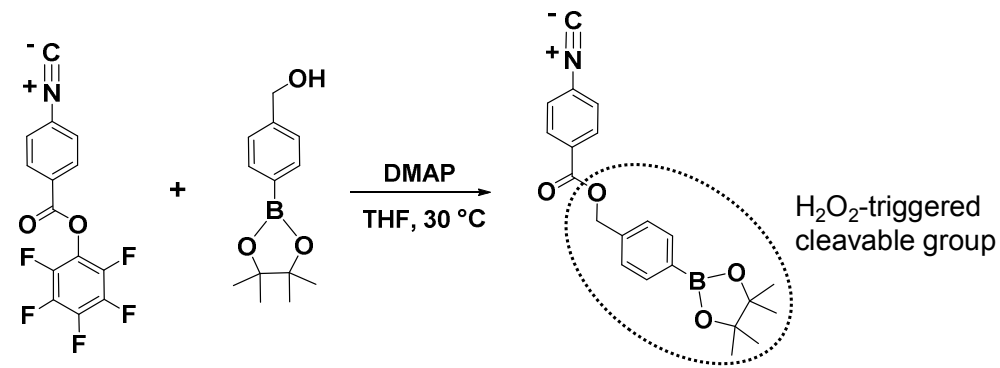

b)

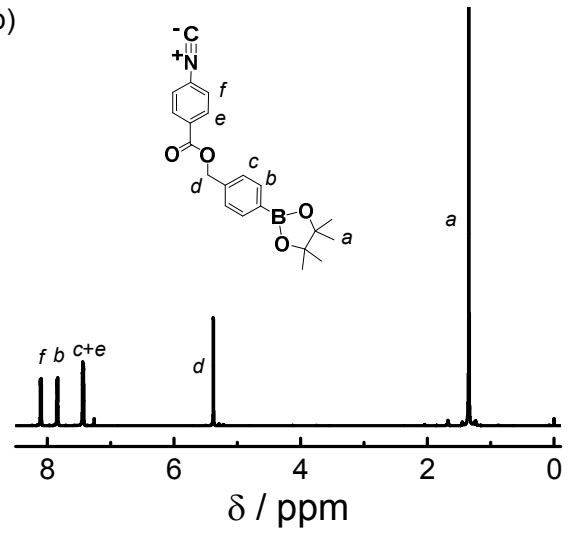

c)

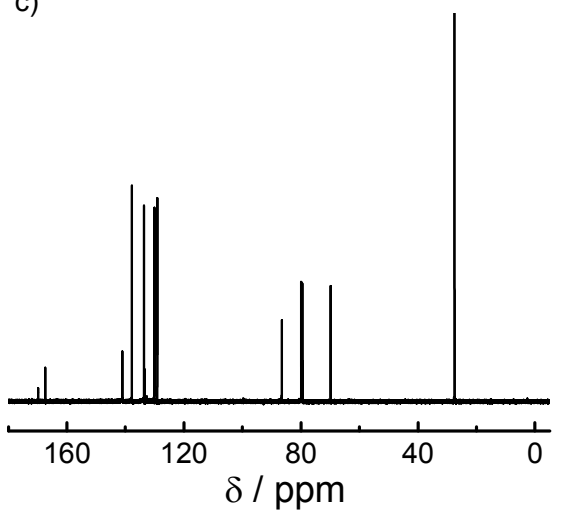

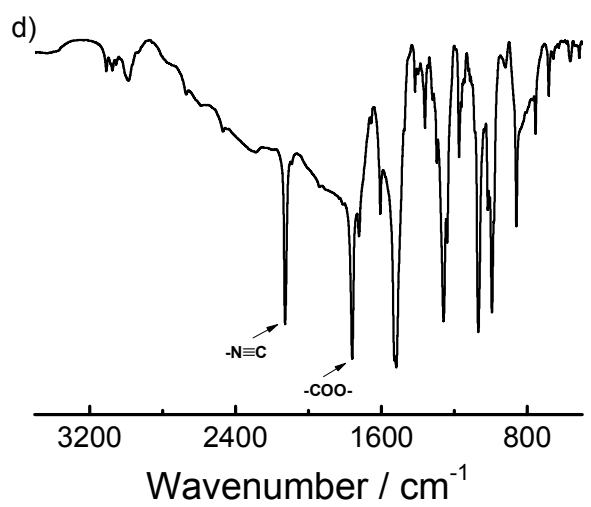

Figure S2. (a) Synthetic route employed for the preparation of $\mathrm{H}_{2} \mathrm{O}_{2}$-responsive phenyl isocyanide monomers $\left(\mathrm{M}_{2}\right)$ through the exchange reaction between pentafluorophenyl ester-functionalized phenyl isocyanide monomer and 4-hydroxymethyl phenyl boronic pinacol ester. (b) ${ }^{1} \mathrm{H} \mathrm{NMR}$, (c) ${ }^{13} \mathrm{C}$ NMR, and (d) FT-IR (using KBr pellets) spectra obtained for $\mathrm{M}_{2}$ at $25{ }^{\circ} \mathrm{C}$. 
a)

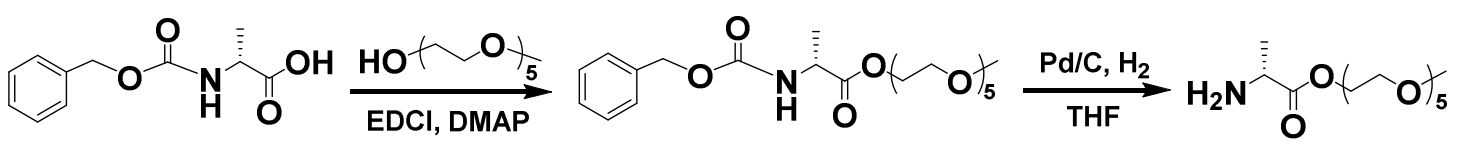

(i)

(ii)

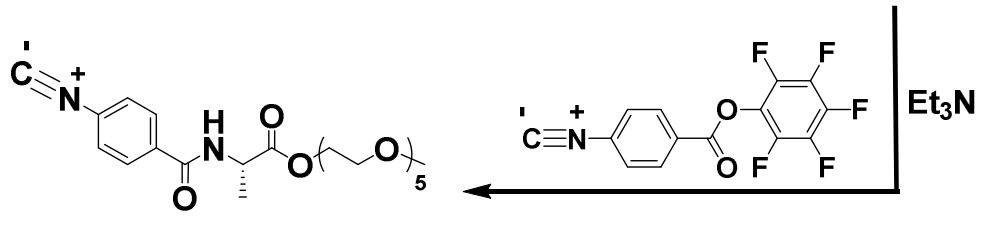

b)

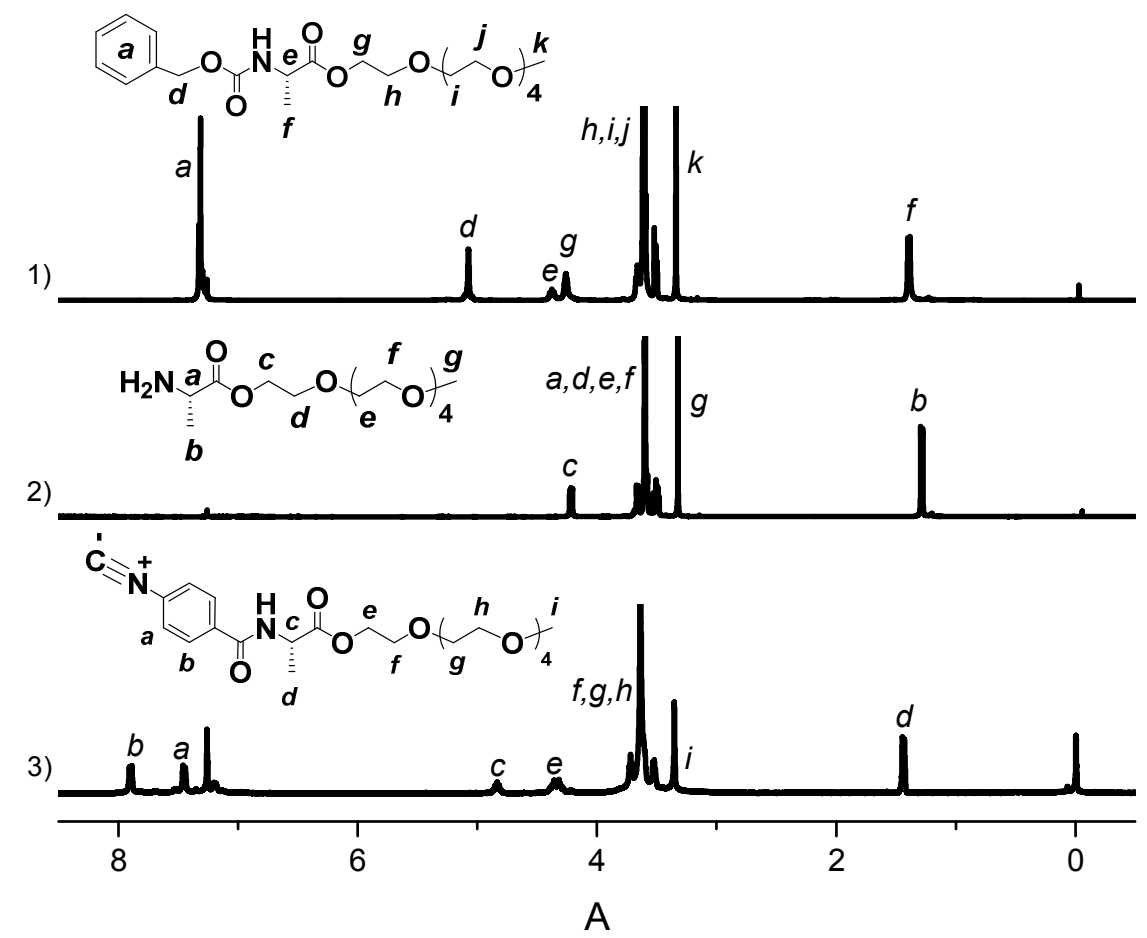

Figure S3. (a) Synthetic routes employed for the preparation of L-hydrophilic phenyl isocyanide monomer $\left(\mathrm{M}_{3}\right)$. (b) ${ }^{1} \mathrm{H}$ NMR spectra obtained for the mediators, $\mathrm{i}$ (b1) and ii (b2) and $\mathrm{M}_{3}(\mathrm{~b} 3$ ). 


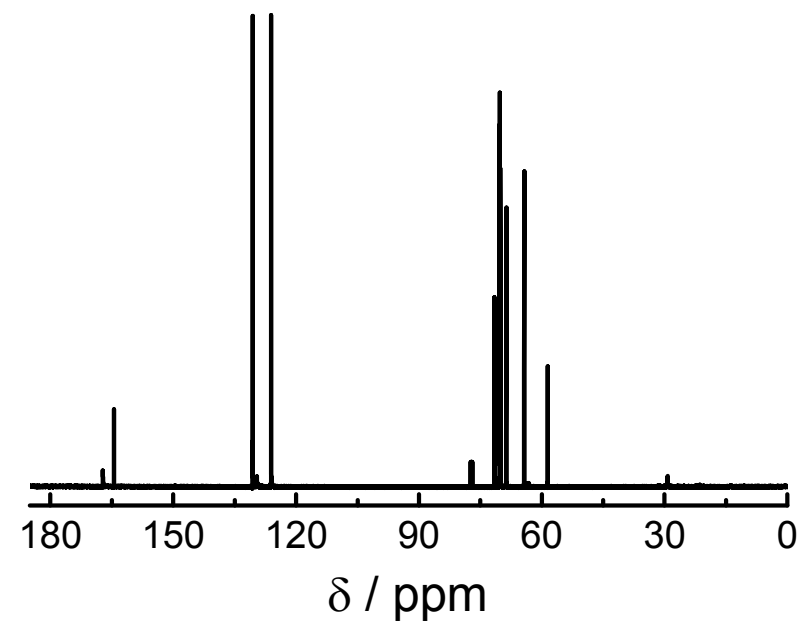

Figure S4. ${ }^{13} \mathrm{C}$ NMR spectrum obtained for $\mathrm{M}_{3}$. 
a)

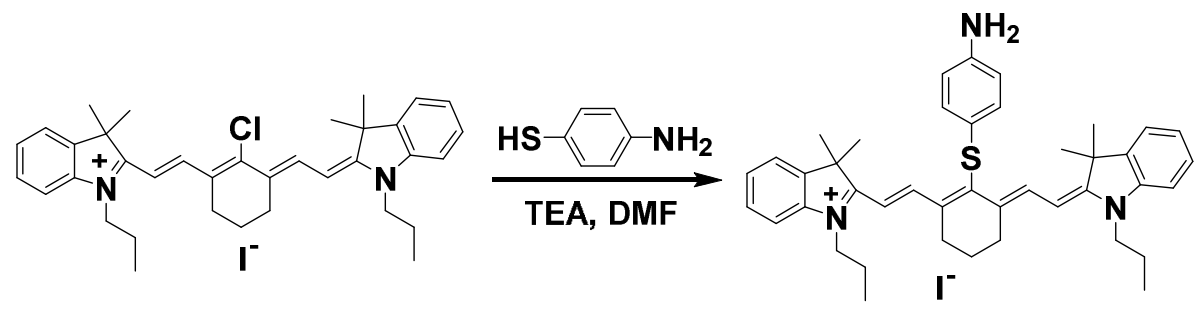

(iii)

b)

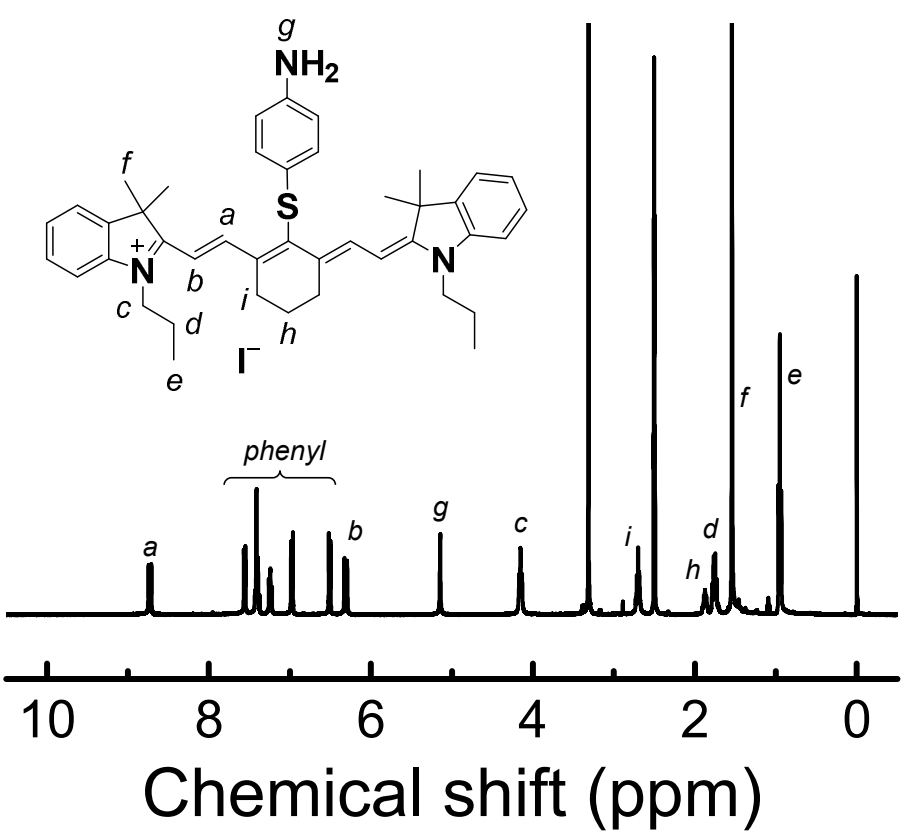

Figure S5. (a) Synthetic route employed for the preparation of aniline-modified IR780 (iii). (b) ${ }^{1} \mathrm{H}$ NMR spectrum obtained for compound iii. 
a)



b)
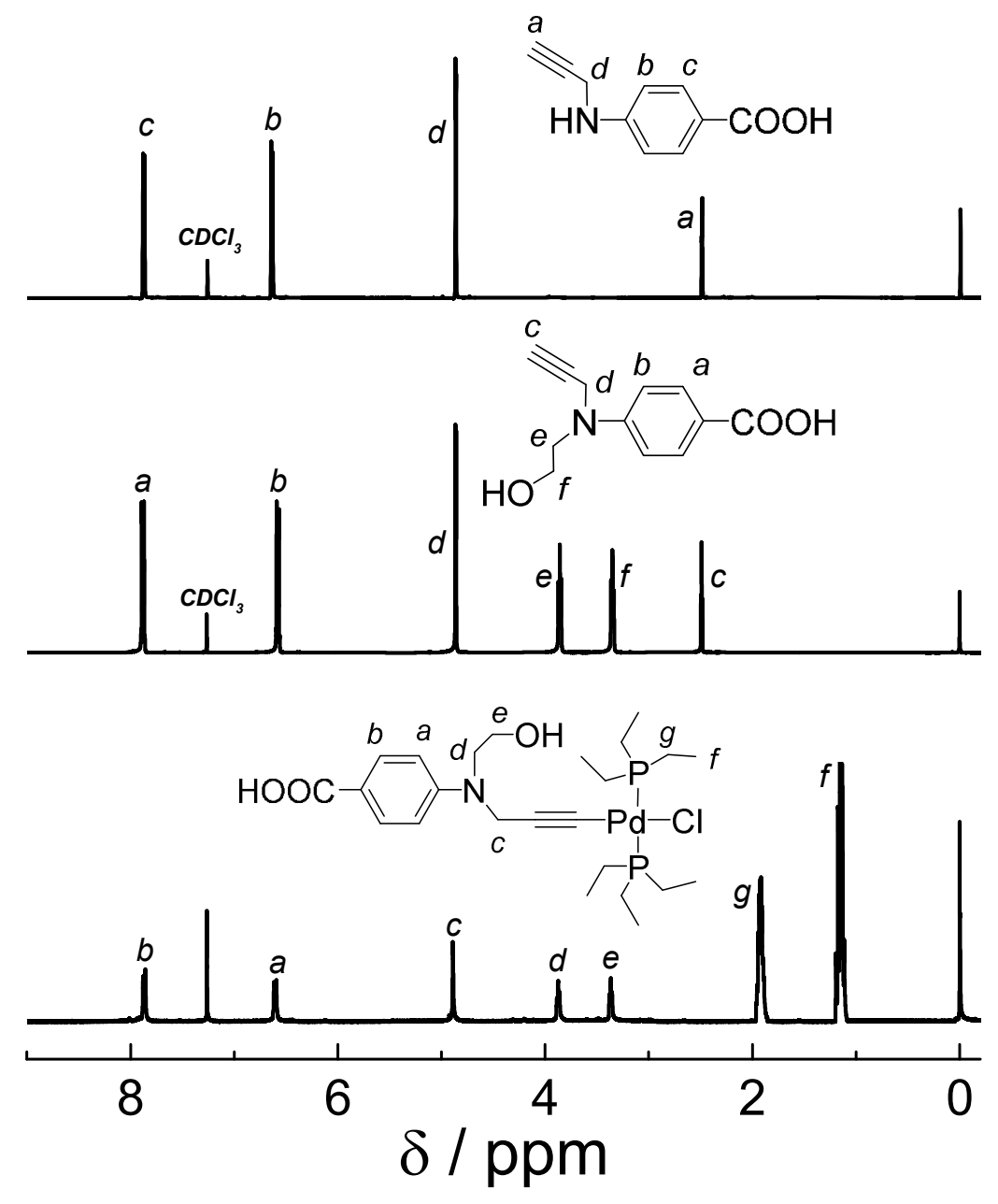

Figure S6. (a) Synthetic routes employed for the preparation of hydroxyl/palladium(II)-modified 4-aminobenzoic acid (iv). (b) ${ }^{1} \mathrm{H}$ NMR spectra obtained for the mediators (v and vi) and compound iv. 
a)

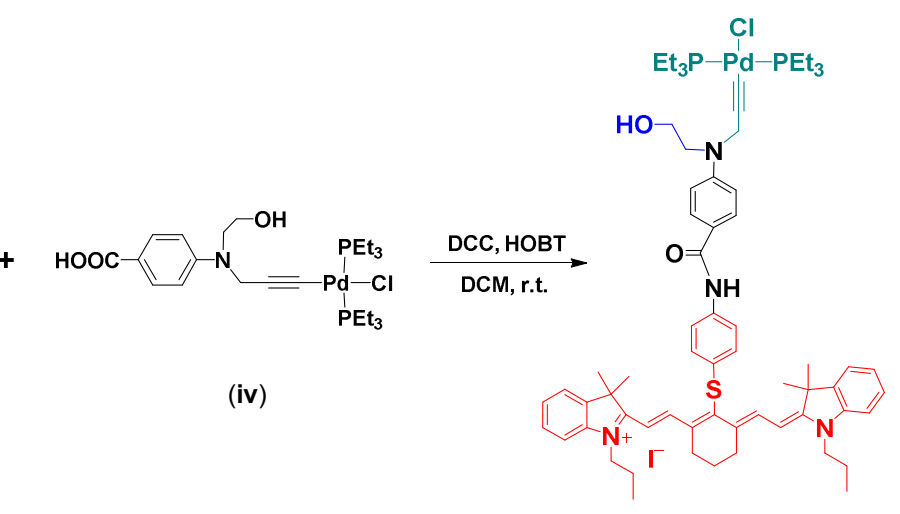

b)

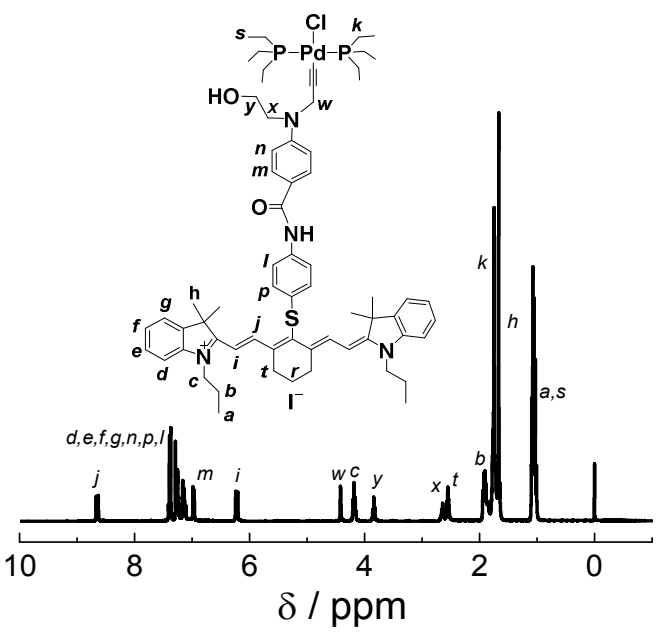

c)

d)

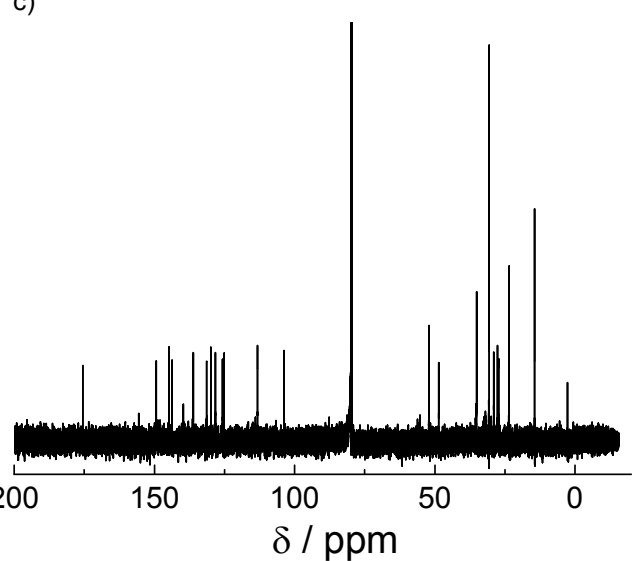

e)
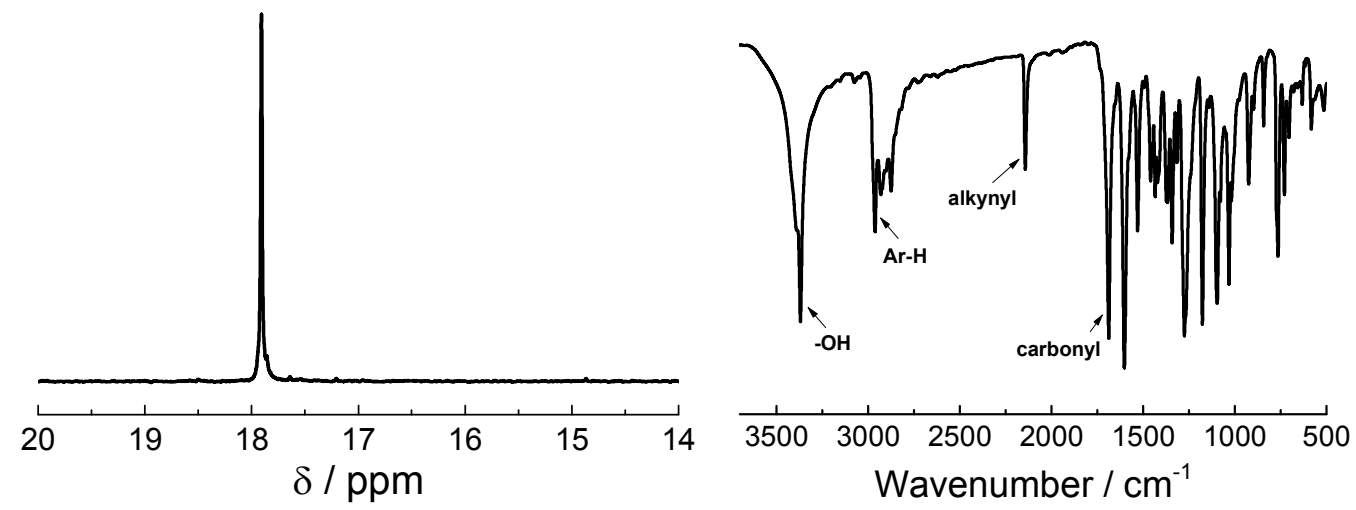

Figure S7. (a) Synthetic route employed for the preparation of IR780 and palladium(II) modified bifunctional catalyst $\left(\mathrm{ClPd}\left(\mathrm{PEt}_{3}\right)_{2}-\mathrm{IR} 780-\mathrm{OH}\right)$ through the condensation reaction between aniline-modified IR780 (iii) and hydroxyl/palladium(II)-modified 4-aminobenzoic acid (iv). (b) ${ }^{1} \mathrm{H}$ NMR, (c) ${ }^{13} \mathrm{C}$ NMR, (d) ${ }^{31} \mathrm{P}$ NMR, and (e) FT-IR spectra obtained for ClPd( $\left.\mathrm{PEt}_{3}\right)_{2}-\mathrm{IR} 780-\mathrm{OH}$ 
catalyst. 


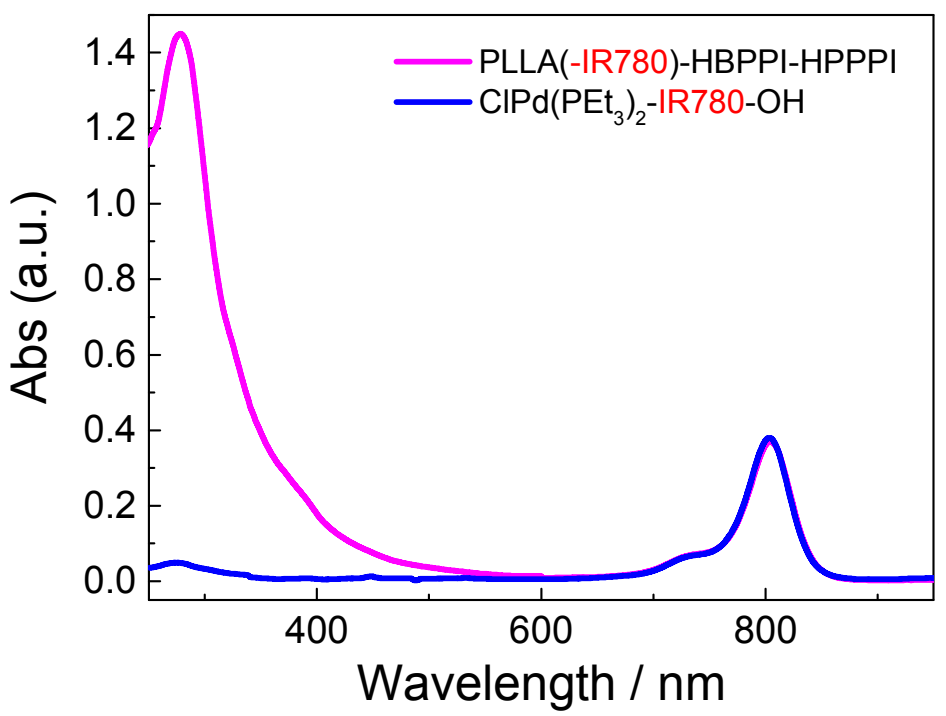

Figure S8. Normalized UV-vis spectra recorded for PLLA(-IR780)-HBPPI-HPPPI triblock copolymers and $\mathrm{ClPd}\left(\mathrm{PEt}_{3}\right)_{2}-\mathrm{IR} 780-\mathrm{OH}$ catalyst. 
a)

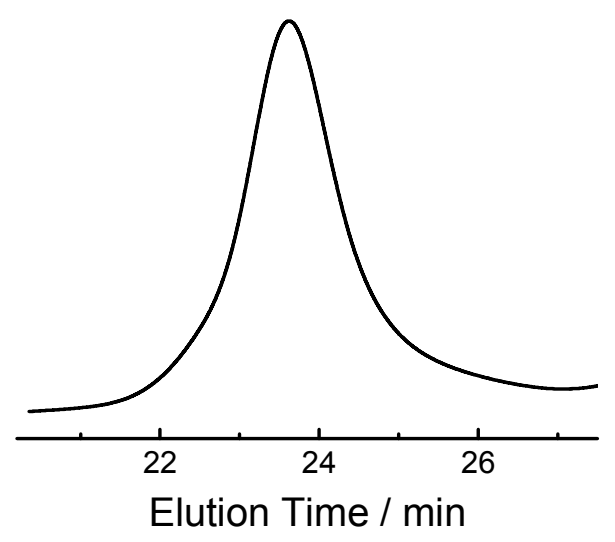

c)

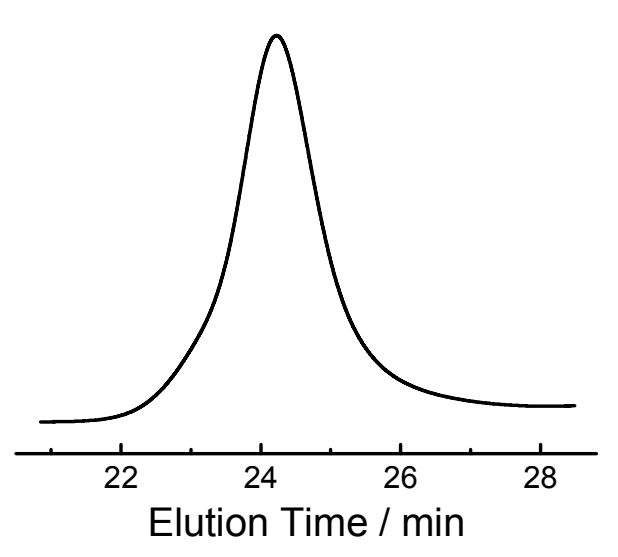

b)

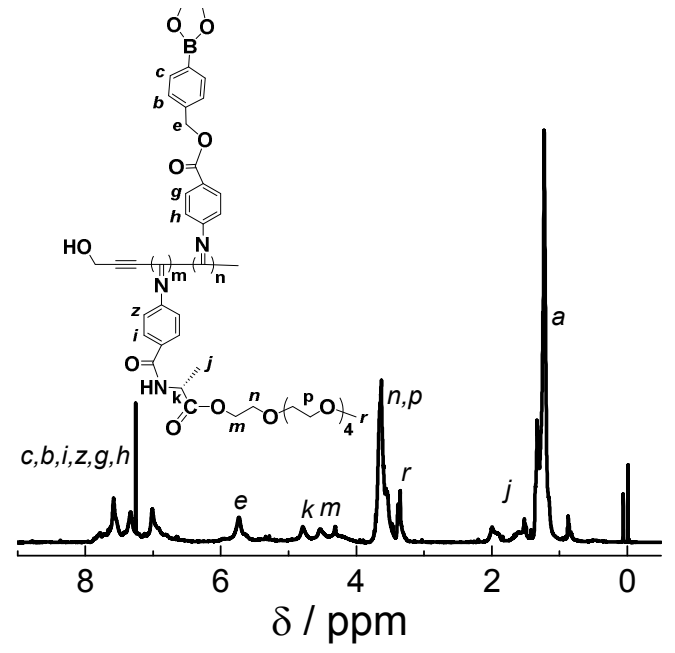

d)

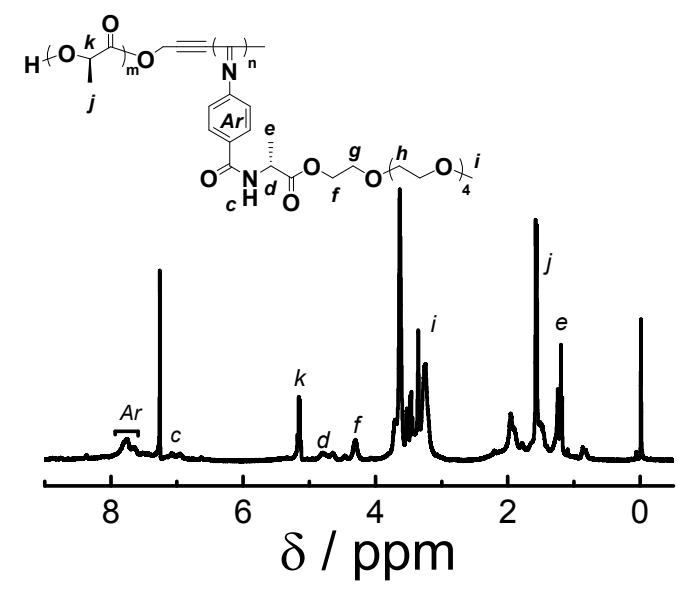

Figure S9. SEC traces and ${ }^{1}$ H NMR spectra obtained for two control samples: (a) HBPPI-HPPPI and (b) PLLA-HPPPI diblock copolymers. 
a)

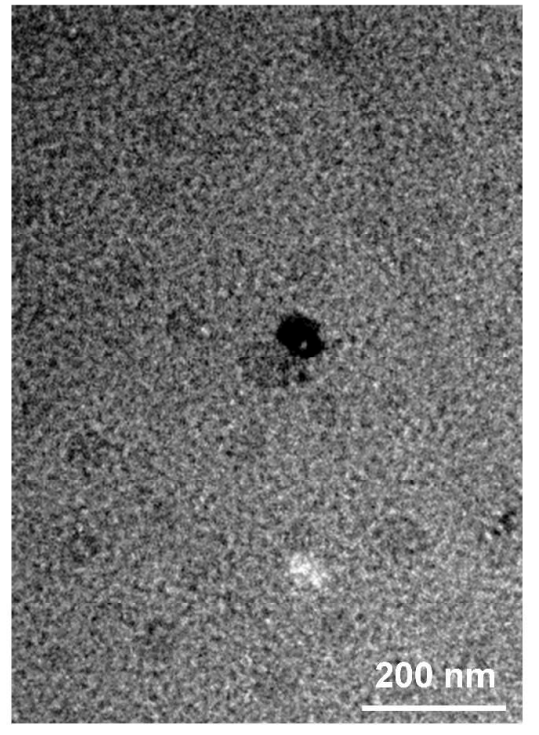

b)

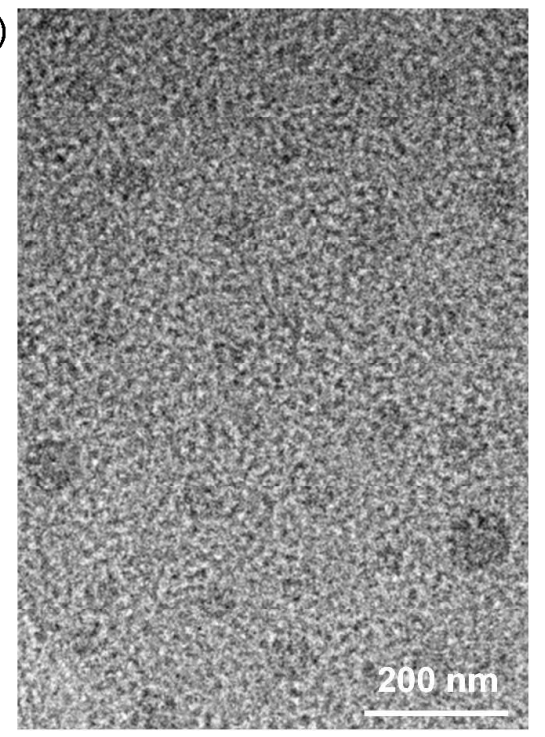

Figure S10. TEM images recorded for the morphologies of (a) HBPPI-HPPPI and (b) PLLA-HPPPI micelles dried from aqueous dispersions $(0.1 \mathrm{~g} / \mathrm{L})$. 

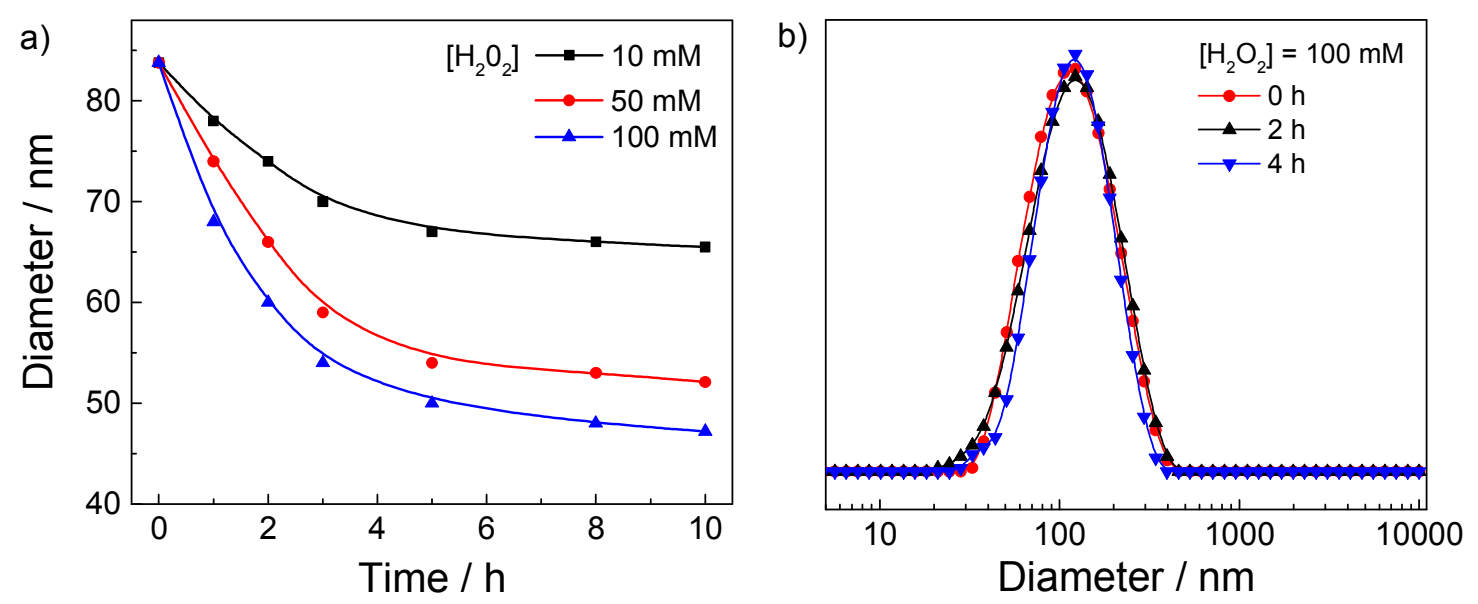

Figure S11. (a) Hydrodynamic diameter change of HBPPI-HPPPI micelles in the presence of different $\mathrm{H}_{2} \mathrm{O}_{2}$ concentrations $(10 \mathrm{mM}, 50 \mathrm{mM}$, and $100 \mathrm{mM})$ as a function of reaction time. (b) Hydrodynamic diameter distribution for the aqueous dispersion of PLLA-HPPPI micelles at different times in the presence of $100 \mathrm{mM} \mathrm{H}_{2} \mathrm{O}_{2}$. 

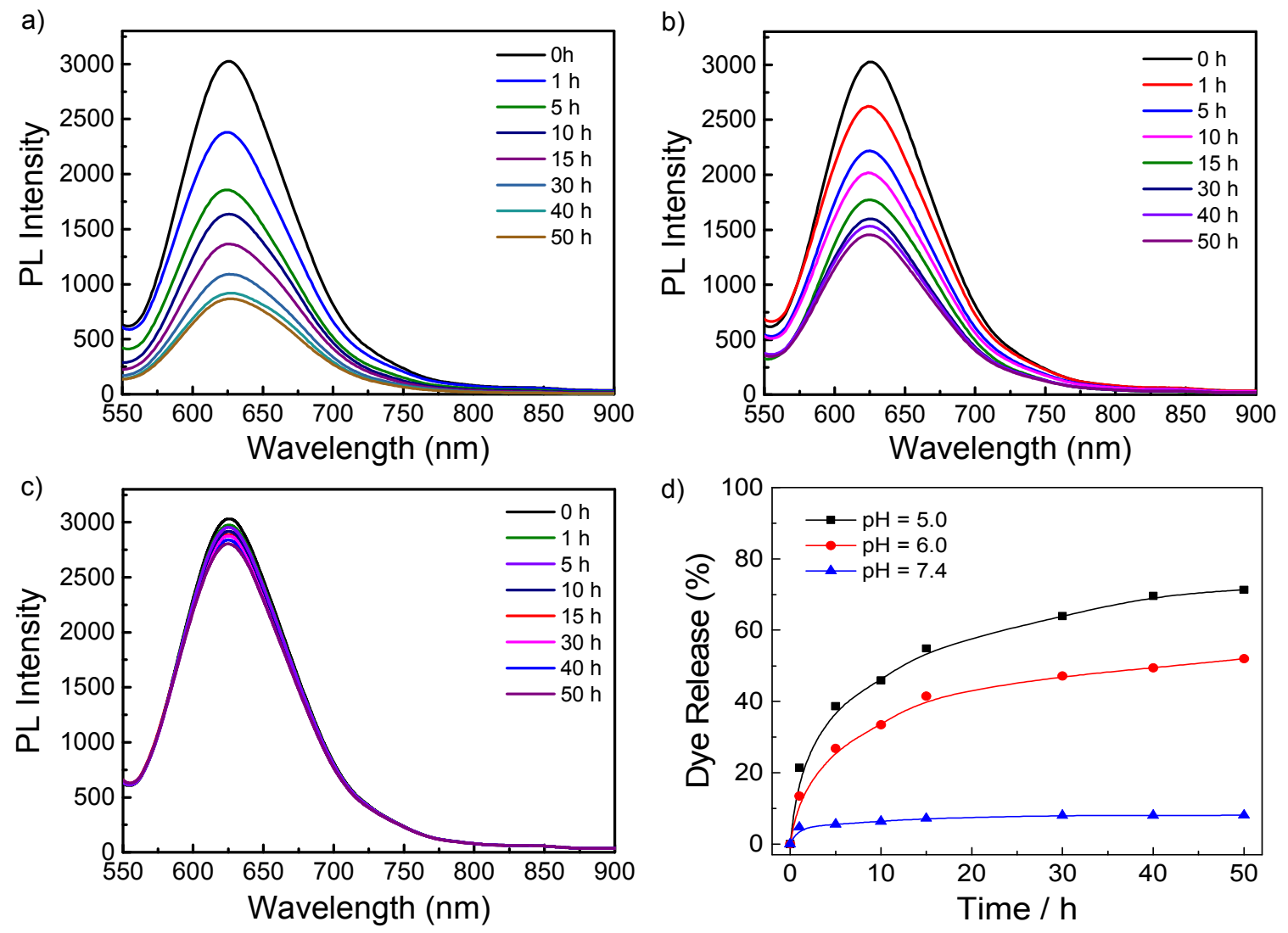

Figure S12. Fluorescence emission spectra $\left(\lambda_{\mathrm{ex}}=550 \mathrm{~nm}\right)$ recorded for the aqueous dispersion of NR@PLLA-HPPPI micelles at pH (a) 5.0, (b) 6.0, and (c) 7.4 in the time range of 0-50 h. (d) In vitro dye release profile of NR@PLLA-HPPPI micelles at varying $\mathrm{pH}$ values, as monitored by the fluorescence intensity changes. 


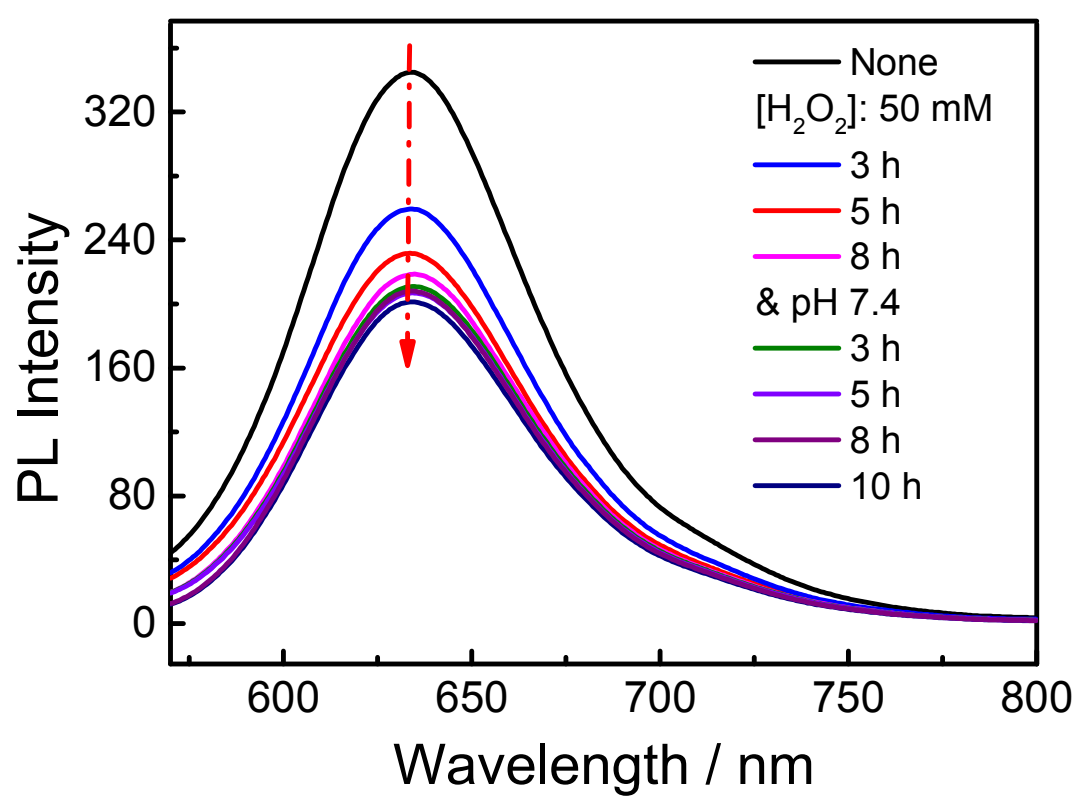

Figure S13. Fluorescence emission spectra $\left(\lambda_{\mathrm{ex}}=550 \mathrm{~nm}\right)$ recorded for the aqueous dispersion of NR@PLLA(-IR780)-HBPPI-HPPPI micelles at different times in the presence of $\mathrm{H}_{2} \mathrm{O}_{2}(50 \mathrm{mM})$ and $\mathrm{HCl}(\mathrm{pH} 7.4)$. 